\title{
EFFECT OF MECHANICAL ACTIVATION ON THE IN SITU FORMATION OF TiB 2 PARTICULATES IN THE POWDER MIXTURE OF TiH 2 AND FeB
}

\begin{abstract}
The in situ formation of $\mathrm{TiB}_{2}$ particulates via an interface reaction between $\mathrm{Ti}$ and $\mathrm{FeB}$ powders was studied. The effects of mechanical activation by high-energy milling on the decomposition of $\mathrm{TiH}_{2}$ and the interface reactions between $\mathrm{Ti}$ and $\mathrm{FeB}$ powders to form $\mathrm{TiB}_{2}$ were investigated. Powder mixtures were fabricated using planetary ball-milling under various milling conditions. The specific ball-milling energy was calculated from the measured electrical power consumption during milling process. High specific milling energy $(152.6 \mathrm{~kJ} / \mathrm{g})$ resulted in a size reduction and homogeneous dispersion of constituent powders. This resulted in a decrease in the decomposition temperature of $\mathrm{TiH}_{2}$ and an increase in the formation reaction of $\mathrm{TiB}_{2}$ particulates in the Fe matrix, resulting in a homogeneous microstructure of nanoscale $\mathrm{TiB}_{2}$ evenly distributed within the Fe matrix. In contrast, the powder mixture milled with low specific milling energy $(36.5 \mathrm{~kJ} / \mathrm{g})$ showed an inhomogeneous microstructure composed of relatively large $\mathrm{Fe}-\mathrm{Fe}_{2} \mathrm{~B}$ particles surrounded by a thin layer of $\mathrm{Fe}-\mathrm{TiB}_{2}$ within a finely dispersed $\mathrm{Fe}-\mathrm{TiB}_{2}$ matrix region.
\end{abstract}

Keywords: mechanical activation, in situ formation, $\mathrm{TiB}_{2}$ particulate, Fe-matrix, specific ball-milling energy

\section{Introduction}

Iron-based composites reinforced by $\mathrm{TiB}_{2}$ particulates have attracted much attention due to their excellent mechanical properties. In situ fabrication processes are known to have more advantages for the composite materials in comparison with the ex situ process due to higher interfacial strength in the clean particle-matrix, fine reinforcement size, and homogeneous particle-size distribution [1]

In situ $\mathrm{Fe}-\mathrm{TiB}_{2}$ composites have been fabricated using various methods, such as laser cladding [2,3], plasma transferred arc (PTA) [4,5], aluminothermic reduction [6], spark plasma sintering (SPS) [7], and self-propagating high-temperature synthesis (SHS) [8-11]. In our previous work [12], Fe-TiB powder was synthesized in situ from an iron boride (FeB) and titanium hydride $\left(\mathrm{TiH}_{2}\right)$ powder mixture by planetary ball-milling and subsequent heat treatment. The mechanical activation of the $\left(\mathrm{FeB}+\mathrm{TiH}_{2}\right)$ powder mixtures by high-energy milling was evident.

The planetary ball-mill is frequently used for enhancing the reaction via mechanical activation. It is important to know the relationship between processing variables and milling energy, as well as the energy transfers to the milled powder during processing. The milling energy can be calculated from mathematical models $[13,14]$ or direct measurement $[15,16]$. A method using the electrical energy consumption during the milling process has been systematically reported by Magini et al. [17], where the energy transferred to the material was studied by measuring the energy input into the mill with empty and filled vials using a high-precision electrical power meter. A summary of the theory of milling energy regarding planetary ball-mill is given in our previous review[18].

In this study, we report the results of specific milling energy during the planetary ball-milling process of a $\left(\mathrm{FeB}+\mathrm{TiH}_{2}\right)$ powder mixture and its effect on the formation of $\mathrm{TiB}_{2}$ particulates in an Fe matrix by the in situ interface reaction between FeB and $\mathrm{TiH}_{2}$ during the heat-treatment.

\section{Experimental procedure}

The powder mixture of $\left(\mathrm{FeB}+\mathrm{TiH}_{2}\right)$ was premixed for $2 \mathrm{~h}$ in a turbular mixer and then milled in a planetary ball-mill (AGO-2). SKD11-steel vials and $\mathrm{WC}$ balls ( $5 \mathrm{~mm}$ in diameter) were used. The ball-to-powder weight ratio was kept at 10:1 for all experiments. The vials were evacuated and filled with $0.3 \mathrm{MPa}$ pure argon gas before each run to prevent oxidation during processing. The powder mixtures were milled with the

\footnotetext{
* FACULTY OF MECHANICAL TECHNOLOGY, INDUSTRIAL UNIVERSITY OF HO CHI MINH CITY, NO. 12 NGUYEN VAN BAO, GO VAP DISTRICT, HO CHI MINH CITY, VIETNAM ** SCHOOL OF ELECTRICAL ENGINEERING, UNIVERSITY OF ULSAN, REPUBLIC OF KOREA

*** SCHOOL OF MATERIALS SCIENCE AND ENGINEERING, UNIVERSITY OF ULSAN, 93 DAEHAK-RO, NAM-GU, ULSAN 44610, REPUBLIC OF KOREA

\# Corresponding author: jskim@ulsan.ac.k
} 
disk-revolution speed of 500 and $700 \mathrm{rpm}$ with a milling time from 0.5 to 5 hours. During the milling process, the energy consumption of the electrical motor of the planetary ball-mill was measured by an electrical power meter (Precision power analyzer YOKOGAWA WT-1800) [18].

To investigate the formation reaction of $\mathrm{TiB}_{2}$ from the $\left(\mathrm{FeB}+\mathrm{TiH}_{2}\right)$ powder mixture fabricated by planetary ball-milling, one gram of as-milled powder mixture was loaded into a small $(20 \mathrm{~mm} \times 20 \mathrm{~mm} \times 30 \mathrm{~mm})$ alumina boat and heated in a tube furnace at various temperatures and holding times. The temperature was chosen based on the thermal analysis results, and the time was programmed up to 2 hours. The heating rate was kept constant at $10^{\circ} \mathrm{C} / \mathrm{min}$, and all samples were synthesized in flowing Ar gas.

Phase analysis was performed using $\mathrm{Cu} \mathrm{K}_{\alpha}$ radiation with an $\mathrm{X}$-ray diffractometer (Rigaku Ultima IV). The microstructure and chemical elements of the composite powders were observed and analyzed by field-emission scanning electron microscope (JEOL JSM-6500F) equipped with energy dispersive spectroscopy.

\section{Results and Discussion}

Figure 1 shows a graph of the energy consumption by the mill as a function of rotation speed and milling time for empty and filled vials under identical conditions. The total energy transferred to the material of $100 \mathrm{~g}$ was $911.2 \mathrm{~kJ}$ and $1,525.9 \mathrm{~kJ}$ for the milling condition of $500 \mathrm{rpm}$ for $5 \mathrm{~h}$ and $700 \mathrm{rpm}$ for $3 \mathrm{~h}$, respectively. The specific energies (the energy per gram of material) transferred to the material were calculated and are

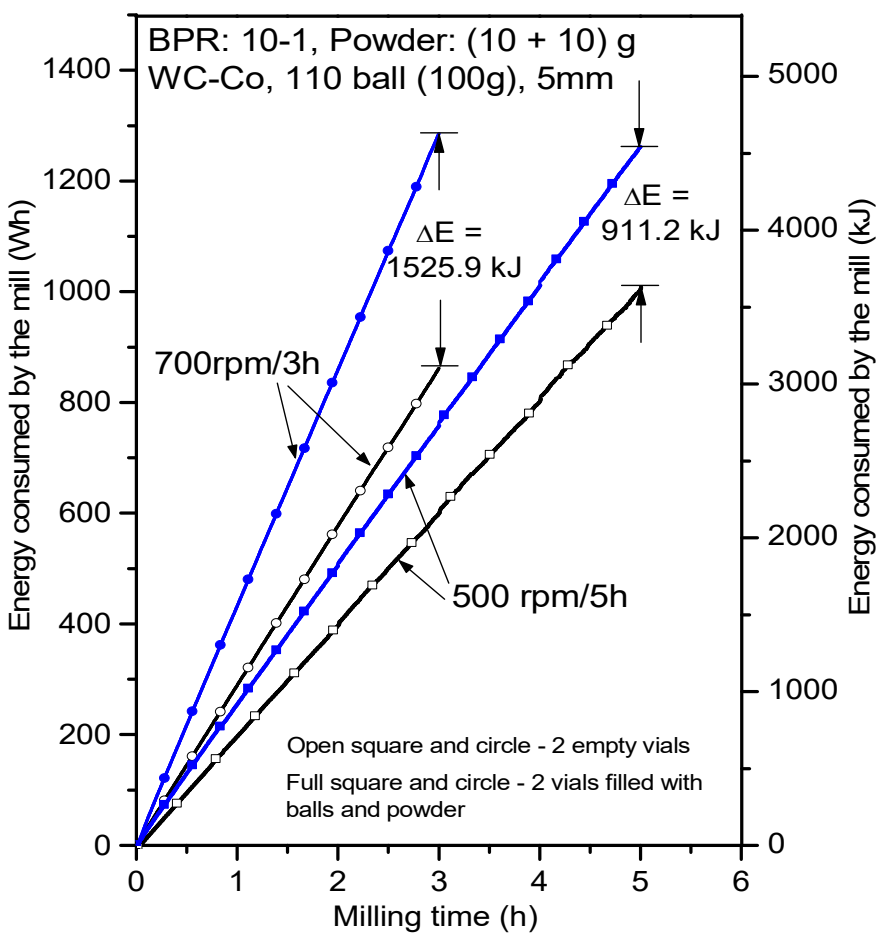

Fig. 1. Change in energy consumption by the mill as a function of rotation speed (500 and $700 \mathrm{rpm}$ ) and milling time for empty (open square and circle) and filled (full square and circle) vials summarized in Table 1. The ratio of the total energy transferred to the material and the total energy consumption of the mill while processing two vials filled with balls and powder shows that approximately $20 \%$ of the energy consumed by the mill is ultimately transferred to the material at the milling speed of $500 \mathrm{rpm}$, with $33 \%$ of energy transferred at $700 \mathrm{rpm}$. It has also been reported in other works that only a small portion of the total input energy can be utilized for pulverizing action and stored as strain energy, structural disorder, additional surfaces, grain boundaries, etc. Most of the energy (about 60\%) is dissipated in the forms of friction, heat, and sound energy during mechanical activation $[19,20]$.

TABLE 1

Specific milling energy transferred to the material for different milling conditions $(\mathrm{kJ} / \mathrm{g})$

\begin{tabular}{|c|c|c|c|c|c|}
\hline \hline rpm & $\mathbf{0 . 5}$ & $\mathbf{1}$ & $\mathbf{2}$ & $\mathbf{3}$ & $\mathbf{5}$ \\
\hline 500 & - & 18.2 & 36.5 & - & 91.1 \\
\hline 700 & 25.4 & 50.9 & 101.7 & 152.6 & - \\
\hline
\end{tabular}

Figure 2 shows the backscattered-electron SEM images of the polished cross-section of the powder mixtures fabricated with different specific milling energy. The angular bright phase with relatively large size are FeB particles, the dark phase dispersed in the matrix is a mixture of fine $\mathrm{TiH}_{2}$ and $\mathrm{FeB}$ particles, and the black dots are pores or impurities present in the initial FeB powder. For the milling energy of $36.5 \mathrm{~kJ} / \mathrm{g}$ (Fig. 2a), the FeB particles remain larger than $1 \mu \mathrm{m}$. With an increase in the specific milling energy to $50.9 \mathrm{~kJ} / \mathrm{g}$, the $\mathrm{FeB}$ particles are drastically reduced to sub-micron scale (Fig. 2b). For the specific milling energy of $152.6 \mathrm{~kJ} / \mathrm{g}$ (Fig. 2c), it is hard to even discern distinct FeB particles within $\mathrm{TiH}_{2}$ powder.

The DSC curve of the $\left(\mathrm{FeB}+\mathrm{TiH}_{2}\right)$ powder mixture milled with different milling energy is given in Fig. 3. It shows two thermal events. In the low-temperature range $\left(<600^{\circ} \mathrm{C}\right)$, the initial powder mixture without high-energy milling shows two thermal events from the decomposition of $\mathrm{TiH}_{2}$. It has been reported that the process takes place in two steps of $\mathrm{TiH}_{2} \rightarrow \mathrm{TiH}_{\mathrm{x}}$ $\rightarrow \alpha$-Ti [21,22]. For the powder mixture milled with milling energy of $25.4 \mathrm{~kJ} / \mathrm{g}$, the decomposition temperature is shifted to around $366^{\circ} \mathrm{C}$ with only one peak. As milling energy is increased $(50.9$ and $152.6 \mathrm{~kJ} / \mathrm{g})$, these endothermic events cease. In these cases, it seems that the dehydrogenation of $\mathrm{TiH}_{2}$ occurs during milling [23]. On further heating, the shift of exothermic peaks are observed from $841^{\circ} \mathrm{C}$ at $25.4 \mathrm{~kJ} / \mathrm{g}$ milling energy to 834,774 and $749^{\circ} \mathrm{C}$ for powder mixtures milled with $36.5,50.9$, and $152.6 \mathrm{~kJ} / \mathrm{g}$, respectively. These reactions show the formation reaction of the $\mathrm{TiB}_{2}$ phase from $\mathrm{Ti}$ and $\mathrm{B}$ in $\mathrm{FeB}$. The changes in temperature of the exothermic peak and time interval for different specific milling energies are summarized in Table 2. The powder milled with the highest energy shows the sharpest peak at the lowest temperature for the shortest time. It should be additionally noted that there is no formation reaction for the unmilled powder mixture. 


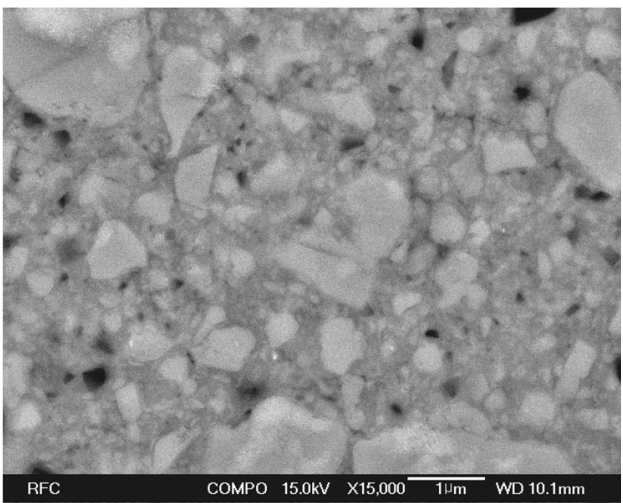

(a)

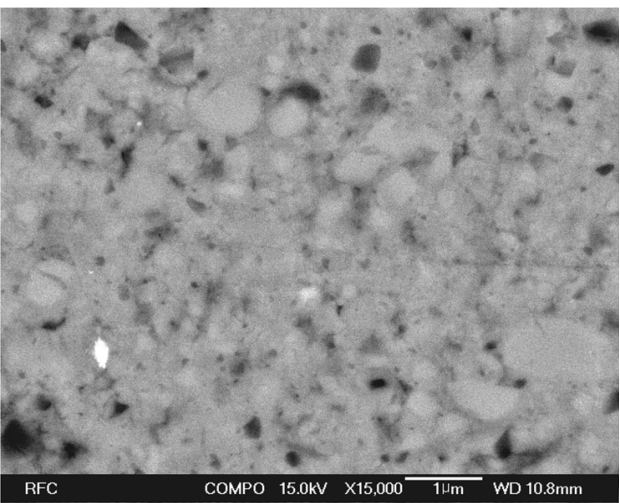

(b)

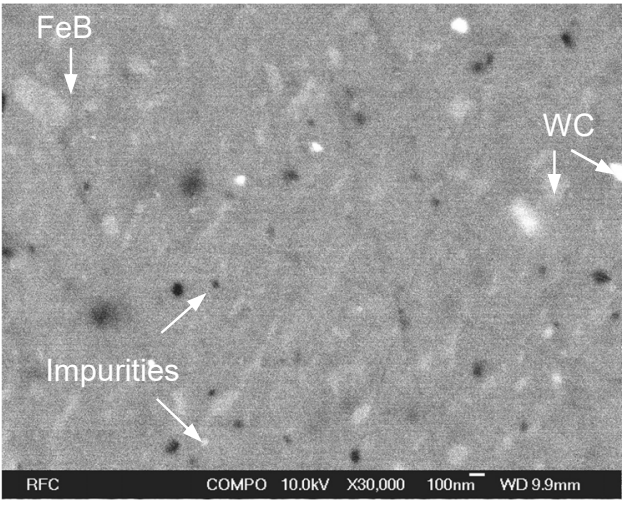

(c)

Fig. 2. Backscattered-electron SEM images of the polished cross-section of $\left(\mathrm{FeB}+\mathrm{TiH}_{2}\right)$ powder mixture fabricated with specific milling energies of (a) $36.5 \mathrm{~kJ} / \mathrm{g}$, (b) $50.9 \mathrm{~kJ} / \mathrm{g}$, and (c) $152.6 \mathrm{~kJ} / \mathrm{g}$

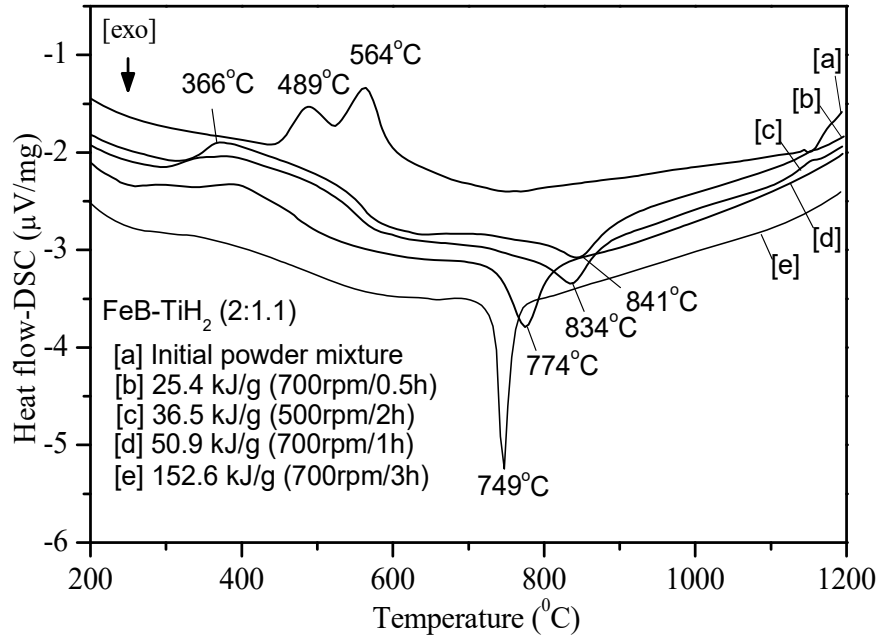

Fig. 3. DSC curves of $\left(\mathrm{FeB}+\mathrm{TiH}_{2}\right)$ powder mixtures milled under various conditions

TABLE 2

Temperatures determined on the DSC curves of as-milled powders with different specific milling energies

\begin{tabular}{|c|c|c|c|c|}
\hline \hline $\begin{array}{c}\text { Spec. Milling } \\
\text { Energy } \\
(\mathbf{k J} / \mathbf{g})\end{array}$ & $\begin{array}{c}\text { Starting } \\
\text { Temp. } \\
\left({ }^{\circ} \mathbf{C}\right)\end{array}$ & $\begin{array}{c}\text { Peak } \\
\text { Temp. } \\
\left({ }^{\circ} \mathbf{C}\right)\end{array}$ & $\begin{array}{c}\text { Finish } \\
\text { Temp. } \\
\left({ }^{\circ} \mathbf{C}\right)\end{array}$ & $\begin{array}{c}\text { Time } \\
\text { interval } \\
(\mathbf{s e c} .)\end{array}$ \\
\hline 36.5 & 727 & 834 & 910 & 370 \\
\hline 50.9 & 705 & 774 & 845 & 279 \\
\hline 152.6 & 690 & 749 & 776 & 172 \\
\hline
\end{tabular}

Figures 4a,b show the XRD-patterns of the $\mathrm{FeB}-\mathrm{TiH}_{2}$ powder mixture fabricated with specific milling energies of $152.6 \mathrm{~kJ} / \mathrm{g}$ and $36.5 \mathrm{~kJ} / \mathrm{g}$. They are subsequently heat-treated at $750^{\circ} \mathrm{C}$ for $0,5,15$ and $30 \mathrm{~min}$ and at $850^{\circ} \mathrm{C}$ for $0,30,60$ and $120 \mathrm{~min}$, respectively. As expected, the powder mixture milled with $152.6 \mathrm{~kJ} / \mathrm{g}$ displays only $\mathrm{Fe}$ and $\mathrm{TiB}_{2}$ phases. The XRD patterns of the powder mixture milled with $36.5 \mathrm{~kJ} / \mathrm{g}$ show a third $\mathrm{Fe}_{2} \mathrm{~B}$ phase in addition to the $\mathrm{Fe}$ and $\mathrm{TiB}_{2}$ phases. The reactions that can occur in our materials system can be summarized as follows:

$$
\begin{aligned}
\mathrm{TiH}_{2} & \rightarrow \mathrm{Ti}+\mathrm{H}_{2} \uparrow \\
\mathrm{Ti}+4 \mathrm{FeB} & \rightarrow \mathrm{TiB}_{2}+2 \mathrm{Fe}_{2} \mathrm{~B} \\
\mathrm{Ti}+2 \mathrm{Fe}_{2} \mathrm{~B} & \rightarrow \mathrm{TiB}_{2}+4 \mathrm{Fe}
\end{aligned}
$$

It is possible for reaction (1) to occur during milling, especially under high milling energy. In our DSC results, we could not observe any peak indicating the decomposition of $\mathrm{TiH}_{2}$ for the powder mixture milled at $152.6 \mathrm{~kJ} / \mathrm{g}$, as shown in Fig. 3. During the process, $\mathrm{Ti}$ and $\mathrm{FeB}$ might interact to form some possible compounds such as $\mathrm{TiB}_{2}, \mathrm{TiB}$, or $\mathrm{Fe}_{2} \mathrm{~B}$. The Gibbs free energies of formation of the possible compounds are [9,24]:

$$
\begin{array}{ll}
\mathrm{Ti}+2 \mathrm{~B} \rightarrow \mathrm{TiB}_{2} & \Delta \mathrm{G}_{1300 \mathrm{~K}}=-275.5{\mathrm{~kJ} \cdot \mathrm{mol}^{-1}}^{-1} \\
2 \mathrm{Fe}+\mathrm{B} \rightarrow \mathrm{Fe}_{2} \mathrm{~B} & \Delta \mathrm{G}_{1300 \mathrm{~K}}=-67.2{\mathrm{~kJ} \cdot \mathrm{mol}^{-1}} \\
\mathrm{Ti}+\mathrm{B} \rightarrow \mathrm{TiB} & \Delta \mathrm{G}_{1300 \mathrm{~K}}=-155.3 \mathrm{~kJ} \cdot \mathrm{mol}^{-1}
\end{array}
$$




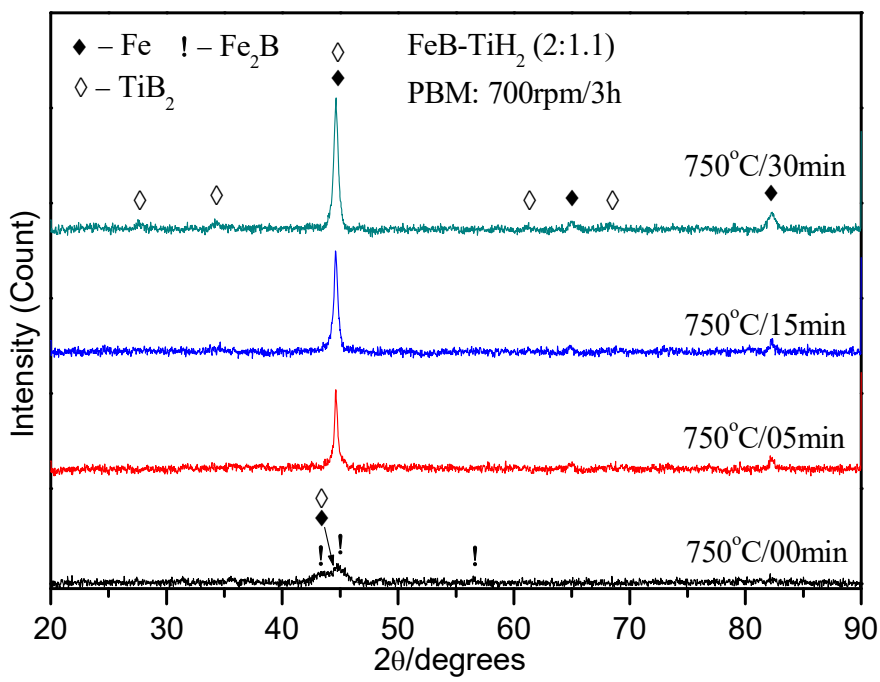

(a)

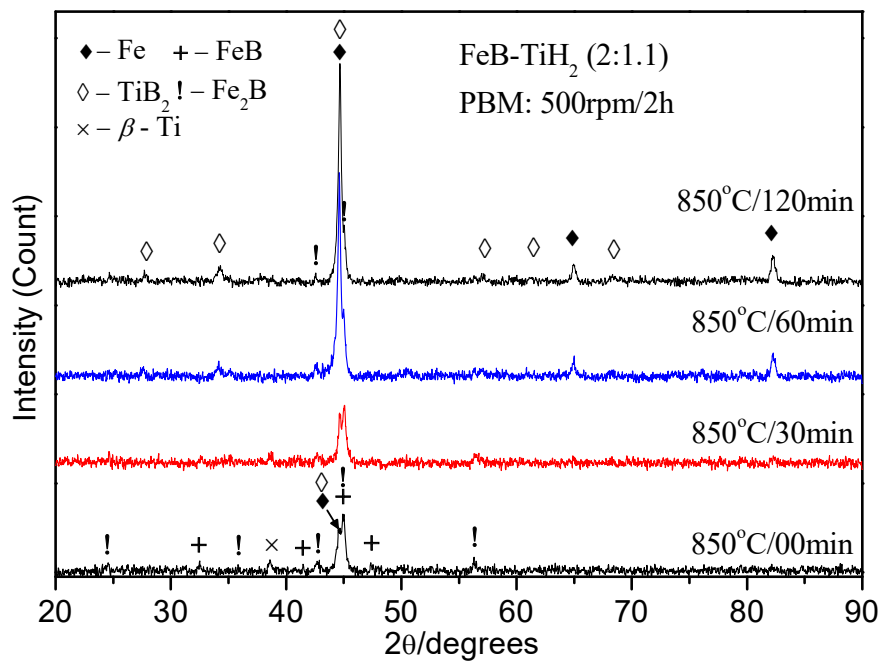

(b)

Fig. 4. XRD-patterns of $\left(\mathrm{FeB}+\mathrm{TiH}_{2}\right)$ powder mixture fabricated with the specific milling energy of (a) $152.6 \mathrm{~kJ} / \mathrm{g}$ and subsequently heat-treated at $750^{\circ} \mathrm{C}$ for $0,5,15$, and $30 \mathrm{~min}$ and (b) $36.5 \mathrm{~kJ} / \mathrm{g}$ and subsequently heat-treated at $850^{\circ} \mathrm{C}$ for $0,30,60$, and $120 \mathrm{~min}$

$$
\begin{aligned}
& \mathrm{Fe}+\mathrm{Ti} \rightarrow \mathrm{FeTi} \quad \Delta \mathrm{G}_{1123 \mathrm{~K}}=-42.1{\mathrm{~kJ} . \mathrm{mol}^{-1}}^{-1} \\
& 2 \mathrm{Fe}+\mathrm{Ti} \rightarrow \mathrm{Fe}_{2} \mathrm{Ti} \quad \Delta \mathrm{G}_{1123 \mathrm{~K}}=-74.1 \mathrm{~kJ} \cdot \mathrm{mol}^{-1}
\end{aligned}
$$

These values indicate that $\mathrm{TiB}_{2}$ is the most thermodynamically favorable and stable phase. The formation of $\mathrm{Fe}_{2} \mathrm{~B}$ can be explained by reaction (2); as $\mathrm{B}$ in $\mathrm{FeB}$ particles reacts with $\mathrm{Ti}$ on the surface to form $\mathrm{TiB}_{2}$, the B-content in $\mathrm{FeB}$ particles is depleted and forces a change from $\mathrm{FeB}$ to $\mathrm{Fe}_{2} \mathrm{~B}$. The existence of $\mathrm{Fe}_{2} \mathrm{~B}$ phase was also reported in previous works using $\mathrm{FeB}$ powder as a starting material $[3,7]$. They reported that the unexpected $\mathrm{Fe}_{2} \mathrm{~B}$ phase was observed due to the incomplete reaction.

In the composite powder fabricated with the highest milling energy $(152.6 \mathrm{~kJ} / \mathrm{g})$ in this study, the FeB particle size is reduced to nanoscale, even in the as-milled state, and the constituent powders are mixed homogeneously. The enhanced reaction of $\mathrm{Ti}$ and $\mathrm{FeB}$ through the short diffusion path, together with mechanical activation, seems to result in a complete forma- tion reaction across the entire region. Very little difference is observed between the backscattered-electron FE-SEM images and the composition (Fig. 5 and Table 3). The composition is well-matched with the expected results (Points (1) and (2)). The results of TEM in our previous work [12] showed that the $\mathrm{TiB}_{2}$ particle size was below $5 \mathrm{~nm}$.

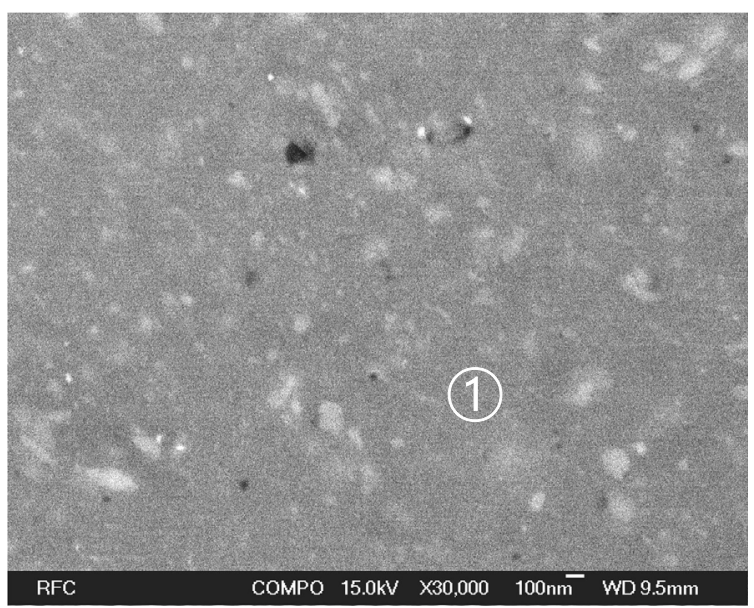

(a)

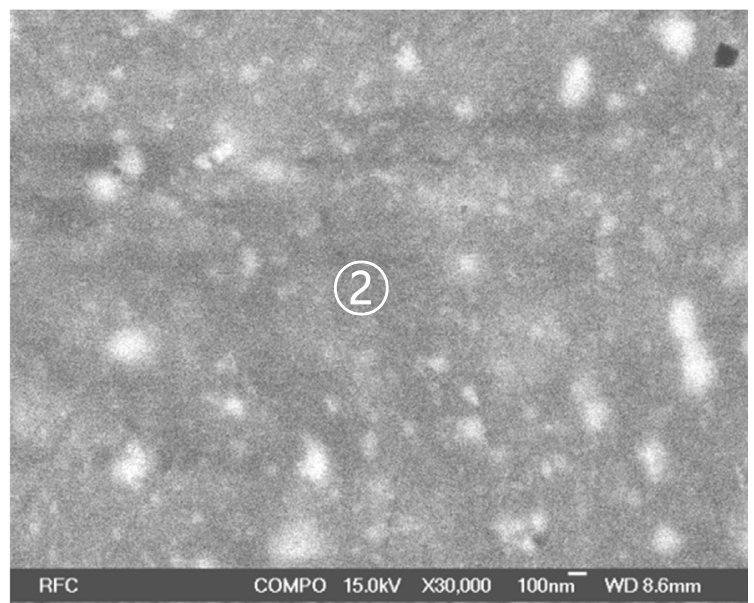

(b)

Fig. 5. Back-scattered electron FE-SEM images of the polished crosssection of $\mathrm{Fe}-\mathrm{TiB}_{2}$ composite powder synthesized from the powder mixture of $\left(\mathrm{FeB}+\mathrm{TiH}_{2}\right)$ fabricated with the specific milling energy of $152.6 \mathrm{~kJ} / \mathrm{g}$ and heat-treated at $750^{\circ} \mathrm{C}$ for (a) 0 and (b) 0.5 hour

TABLE 3

Results of EDS point-analysis for the points marked on Figs. 5 and 6

\begin{tabular}{|c|c|c|c|c|}
\hline \multirow{2}{*}{ Marking points } & \multicolumn{3}{|c|}{ Composition (at.\%) } & \multirow{2}{*}{ Possible phases } \\
\cline { 2 - 4 } & $\mathbf{F e}$ & $\mathbf{B}$ & $\mathbf{T i}$ & \\
\hline (1) & 40.0 & 39.4 & 20.6 & $\mathrm{Fe}-\mathrm{TiB}_{2}$ \\
\hline (2) & 40.3 & 37.8 & 21.9 & $\mathrm{Fe}-\mathrm{TiB}_{2}$ \\
\hline (3) & 45.0 & 47.3 & 7.7 & $\mathrm{FeB}$ \\
\hline (4) & 48.1 & 39.2 & 12.7 & $\mathrm{Fe}^{-} \mathrm{Fe}_{2} \mathrm{~B}, \mathrm{TiB}_{2}$ \\
\hline (5) & 26.4 & 49.1 & 24.4 & $\mathrm{Fe}-\mathrm{TiB}_{2}$ layer \\
\hline (6) & 29.6 & 36.5 & 33.9 & $\mathrm{Fe}-\mathrm{TiB}_{2}+\mathrm{Ti}$ \\
\hline
\end{tabular}

In contrast, the composite powder fabricated with low specific milling energy $(36.5 \mathrm{~kJ} / \mathrm{g})$ revealed inhomogeneous 
microstructures. The results of the backscattered-electron SEM images and EDS line analysis are given in Fig. 6. At the initial stage of the reaction (Fig. 6a), the phases found in the XRD peak are $\mathrm{FeB}, \mathrm{Fe}_{2} \mathrm{~B}, \mathrm{Fe}$ and $\mathrm{TiB}_{2}$. The result of EDS line-analysis (Line A) shows high concentrations of $\mathrm{Fe}$ and $\mathrm{B}$ at the center of the particle. This means that the coarse FeB particles remained even after the milling process. In the case of large FeB particles, it seems that $\mathrm{TiB}_{2}$ is formed initially on the surface of $\mathrm{FeB}$ in a layer of $\mathrm{Fe}-\mathrm{TiB}_{2}$, which gradually grows into the $\mathrm{FeB} / \mathrm{Fe}_{2} \mathrm{~B}$ core. Compared to the large $\mathrm{FeB}$ particle, the small particle shows a less remarkable difference (Line B). At the final stage of the reaction (Fig. 6b), a thin dark layer is observed around the bright Fe-rich phase. It should be noted that the FeB phase is not observed in XRD analysis in this powder. Thus, the bright phase cannot be FeB. Rather, it seems that the bright phase is $\mathrm{Fe}_{2} \mathrm{~B}$ and the thin dark layer is $\mathrm{Fe}-\mathrm{TiB}_{2}$. This incomplete reaction might prevent the large $\mathrm{FeB}$ particles from all further interdiffusion with the interface and preserve a small amount of $\mathrm{Fe}_{2} \mathrm{~B}$ within the powder even at the highest temperature of $850^{\circ} \mathrm{C}$ and the longest holding time of 2 hours. The EDS result showed high boron and titanium at the dark ring (5), indicating that the $\mathrm{TiB}_{2}$ phase is formed. The EDS-Line D shows the homogeneous distribution of $\mathrm{Fe}, \mathrm{Ti}$, and $\mathrm{B}$ in this region.
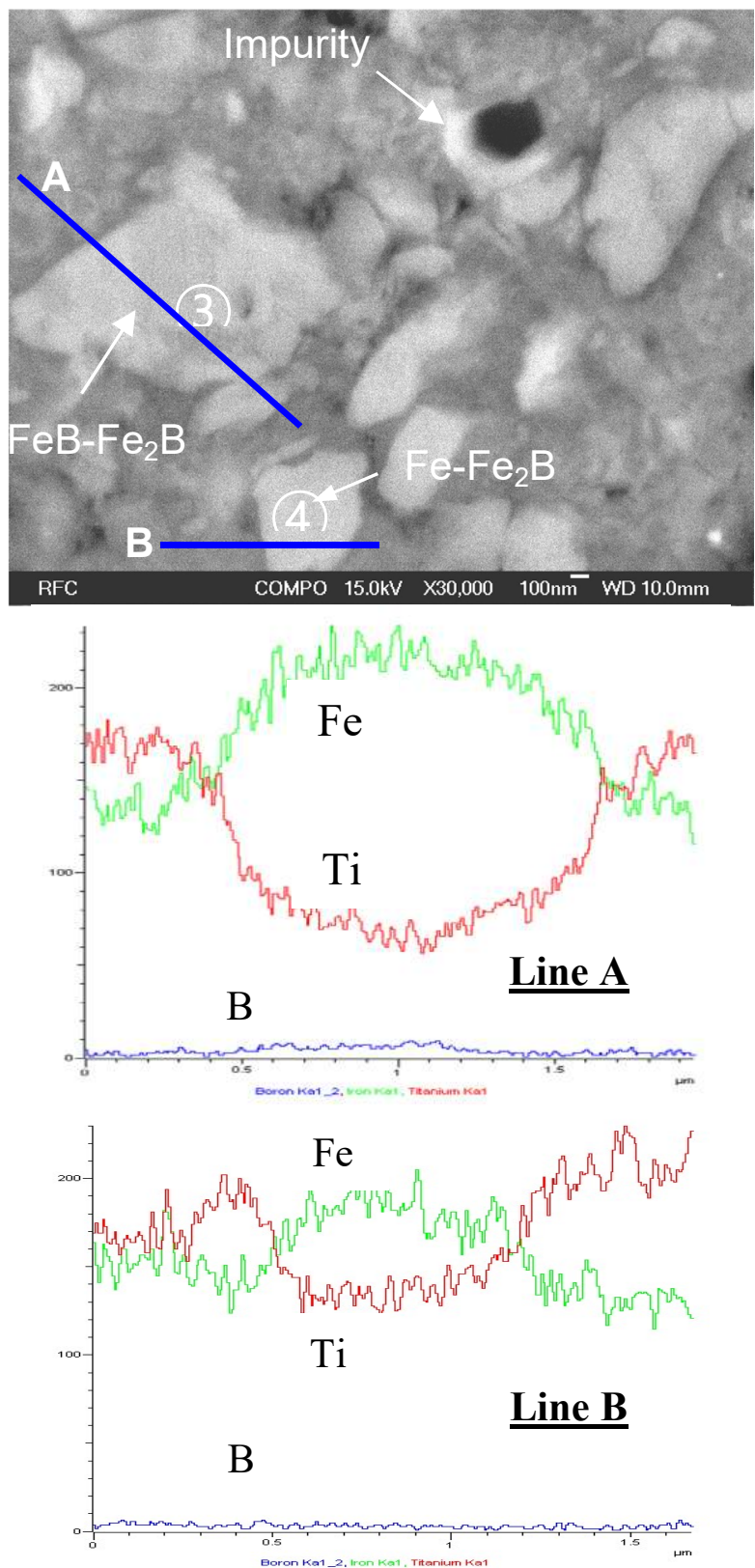

(a)
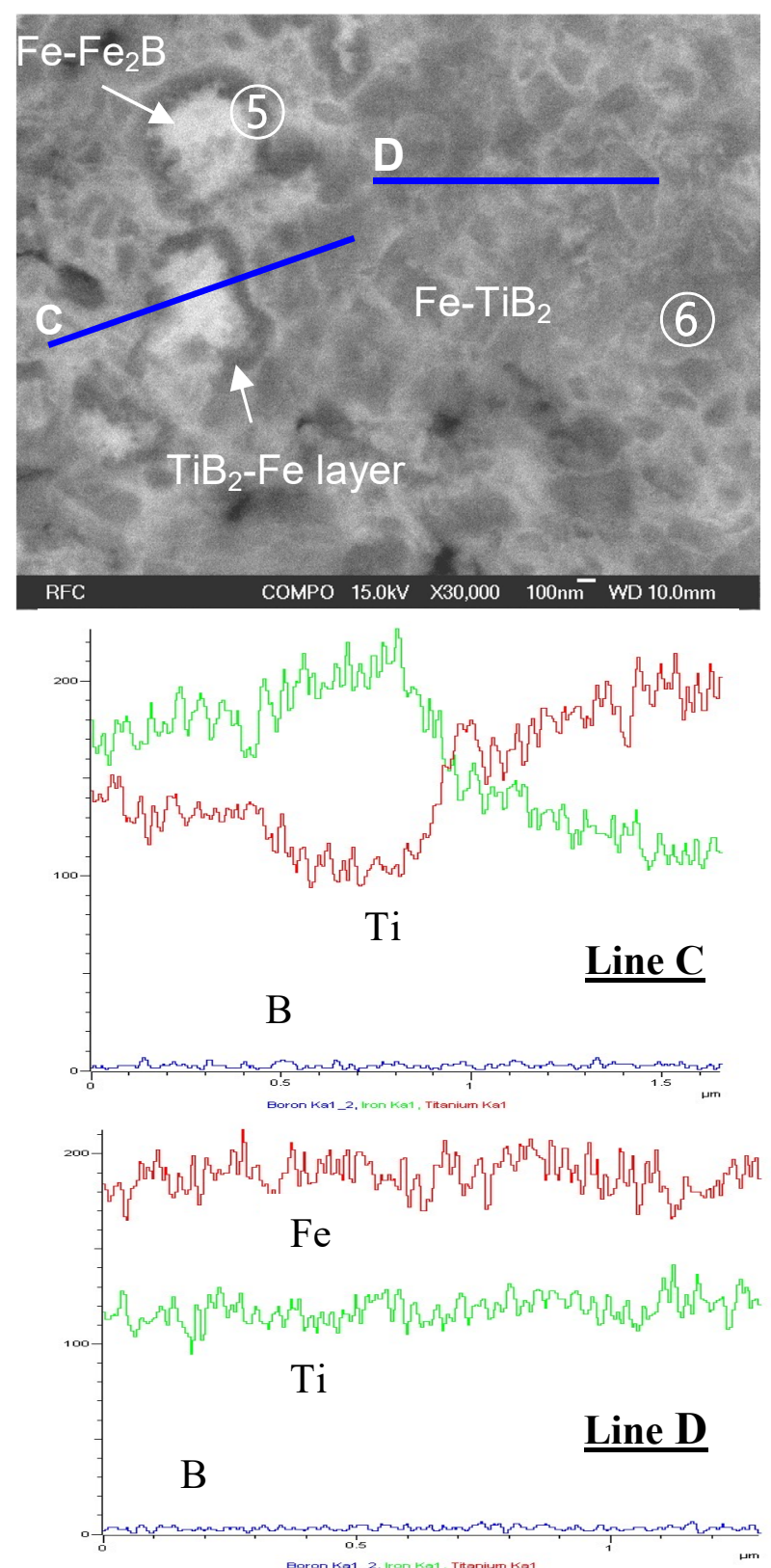

(b)

Fig. 6. Back-scattered electron FE-SEM images of the polished cross-section of $\mathrm{Fe}-\mathrm{TiB}_{2}$ composite powder synthesized from the powder mixture of $\left(\mathrm{FeB}+\mathrm{TiH}_{2}\right)$ fabricated with the specific milling energy of $36.5 \mathrm{~kJ} / \mathrm{g}$ and heat-treated at $850^{\circ} \mathrm{C}$ for (a) 0 and (b) 2 hours together with the profiles of EDS line-analysis for the elements of $\mathrm{Fe}, \mathrm{Ti}$ and $\mathrm{B}$ 
1398

\section{Conclusions}

From the results of this study on the in situ formation of $\mathrm{TiB}_{2}$ particulates in an Fe matrix from the mixture of titanium hydride $\left(\mathrm{TiH}_{2}\right)$ and iron boride $(\mathrm{FeB})$ powders mechanically-activated by high-energy milling, we make the following conclusions.

The increase in specific milling energy results in size reduction and homogeneous dispersion of constituent powders. The decomposition of $\mathrm{TiH}_{2}$ occurs at lower temperature and even during the milling process for high specific milling energy.

Mechanical activation due to high specific milling energy $(152.6 \mathrm{~kJ} / \mathrm{g})$ enhances the in situ reaction of Ti and $\mathrm{FeB}$ to form $\mathrm{TiB}_{2}$ particulates in the Fe matrix, even at the fairly low temperature of $749^{\circ} \mathrm{C}$, compared to the as-mixed powders.

The powder mixture milled with low specific milling energy $(36.5 \mathrm{~kJ} / \mathrm{g})$ showed an inhomogeneous microstructure composed of relatively large $\mathrm{Fe}_{-} \mathrm{Fe}_{2} \mathrm{~B}$ particles surrounded by a thin layer of $\mathrm{Fe}-\mathrm{TiB}_{2}$ within a finely dispersed $\mathrm{Fe}-\mathrm{TiB}_{2}$ matrix region.

\section{Acknowledgements}

This work was supported by the 2015 Research Fund of University of Ulsan.

\section{REFERENCES}

[1] R.M. Aikin, JOM 49, 35-39 (1997).

[2] B. Du, Z. Zou, X. Wang, S. Qu, Appl. Surf. Sci. 254, 6489-6494 (2008).

[3] B. Du, Z. Zou, X. Wang, S. Qu, Mat. Lett. 62, 689-691 (2008).

[4] M. Darabara, G.D. Papadimitriou, L. Bourithis, Surf. Coat. Technol. 201, 3518-3523 (2006).

[5] W. Xibao, W. Xiaofeng, S. Zhongquan, Surf. Coat. Technol. 192, 257-262 (2005).

[6] A. Anal, T.K. Bandyopadhyay, K. Das, J. Mater. Process. Technol. 172, 70-76 (2006).
[7] B. Li, Y. Liu, H. Cao, L. He, J. Li, J. Mater. Sci. 44, 3909-3912 (2009).

[8] O.K. Lepakova, L.G. Raskolenko, Y.M. Maksimov, Combust., Explos. Shock Waves 36, 575-581 (2000).

[9] C.C. Degnan, P.H. Shipway, Metall. Mater. Trans. A33, 2973-2983 (2002).

[10] L. Gai, M. Ziemnicka-Sylwester, Int. J. Refract. Met. Hard Mater. 45, 141-146 (2014).

[11] O.K. Lepakova, L.G. Raskolenko, Y.M. Maksimov, J. Mater. Sci. 39, 3723-3732 (2004).

[12] X.K. Huynh, Fabrication of Fe-TiB2 Nanocomposite with Use of High-energy Milling Followed by in situ Reaction Synthesis and Sintering, PhD Thesis, University of Ulsan, Ulsan, Korea.

[13] N. Burgio, A. Iasonna, M. Magini, S. Martelli, F. Padella, Il Nuovo Cimento D 13, 459-476 (1991).

[14] B.S. Murty, M. Mohan Rao, S. Ranganathan, Acta Metall. Mater. 43, 2443-2450 (1995).

[15] A. Iasonna, M. Magini, Acta Mater. 44, 1109-1117 (1996).

[16] M. Magini, C. Colella, A. Iasonna, F. Padella, Acta Mater. 46, 2841-2850 (1998).

[17] M. Magini, A. Iasonna, Mater. Trans. JIM 36, 123-133 (1995).

[18] H.X. Khoa, S.W. Bae, S.W. Bae, B.W. Kim, J.S. Kim, J. Korean Powder Metall. Inst. 21, 155-164 (2014).

[19] L.Y. Putsov, S.D. Kaloshkin, V.V. Tcherdyntsev, I.A. Tomilin, E.V. Shelekhov, A.I. Salimon, J. Metastable Nanocryst. Mater. 10, 373-378 (2001).

[20] C. Sasikumar, S. Srikanth, N.K. Mukhopadhyay, S.P. Mehrotra, Miner. Eng. 22, 572-574 (2009).

[21] A.R. Gromov, N.N. Kouznetsov, S.L. Yuding, V.V. Lunin, J. Alloys Compd. 261, 269-272 (1997).

[22] C.C. Yang, H. Nakae, J. Alloys Compd. 313, 188-191 (2000).

[23] S.Y. Bae, T.K. Sung, W.H. Jung, I.S. Ahn, D.K. Park, Y.Y. Kim, J. Kor. Inst. Met. Mater. 43, 533-537 (2005).

[24] J.A. van Beek, A.A. Kodentsov, F.J.J. van Loo, J. Alloys Compd. 221, 108-113 (1995). 